\title{
Respiratory cancer in chrysotile textile and mining industries: exposure inferences from lung analysis
}

\author{
P SEBASTIEN,' J C McDONALD,' A D McDONALD,' B CASE,' R HARLEY \\ From the School of Occupational Health, ${ }^{I}$ McGill University, Montreal, PQ H3A 1A3, Canada, and \\ Department of Pathology, ${ }^{2}$ Medical University of South Carolina, Charleston, SC 29425-0689, USA
}

ABSTRACT In an attempt to explain the much greater risk of respiratory cancer at the same cumulative exposure in asbestos textile workers in Charleston, South Carolina, than in Quebec miners and millers, both exposed to chrysotile from the same source, 161 lung tissue samples taken at ${ }_{-}^{\omega}$ necropsy from dead cohort members were analysed by transmission electron microscopy. Altogether $\vec{\circ}$ 1828 chrysotile and 3270 tremolite fibres were identified; in both cohorts tremolite predominated ando fibre dimensions were closely similar. Lung fibre concentrations were analysed statistically $(a)$ in $32 \rightarrow$ paired subjects matched for duration of employment and time from last employment to death and $(b) 3$ in 136 subjects stratified by the same time variables. Both analyses indicated that the Quebec/莡 Charleston ratios for chrysotile fibre concentration in lung tissue were even higher than the corresponding ratios of estimated exposure intensity (mpcf). After allowance for the fact that $\vec{\infty}_{\infty}^{\circ}$ regression analyses suggested that the proportion of tremolite in dust was probably $2 \cdot 5$ times higher in. ${ }^{\bullet}$ Thetford Mines, Quebec, than in Charleston, the results from both matched pair and stratification: analyses of tremolite fibre concentrations in lung were almost the same as for chrysotile. It is concluded that neither fibre dimensional differences nor errors in estimation of exposure can explain the higher risks of lung cancer observed in asbestos textile workers. The possible co-carcinogenic role $e_{\mathbb{D}}^{\circ}$ of mineral oil used in the past in asbestos textile plants to control dust provides an alternative hypothesis deserving consideration.

After many years of asbestos research, exposure response in man is still poorly understood. By combining factors such as fibre type, length, diameter, and numerical or gravimetric concentration, it is theoretically possible to construct several indices of exposure intensity, each of different biological relevance. Surface structure and chemistry should also be taken into account. Practically, however, information on exposure intensity is at best limited to one index. Industrial hygienists currently measure the concentration of fibres with a length greater than 5 microns and a diameter greater than about 0.25 micron $(\mathrm{f} / \mathrm{ml})$. In the past, impinger methods were used to measure dust in million of particles per cubic foot (mpcf); in asbestos industries the particles were generally not fibrous or longer than $0.75 \mu \mathrm{m}$. $^{1}$

Quantitative studies of exposure response entail reconstruction of exposures in industries where conditions and monitoring techniques have changed over the years and where the high and more important

Accepted 15 February 1988 exposures of the past were seldom documented. This difficult exercise has been attempted in nine industria胥 populations. ${ }^{2}$ Among these were the chrysotile miners and millers of Quebec ${ }^{34}$ and the chrysotile textile workers of Charleston, South Carolina. ${ }^{5}$ Lineas relations between excess mortality from respiratoris cancer and cumulative exposure in these two popula tions (fig 1) illustrate the problem considered in the present report. In both cohorts cumulative exposures (mpcf.y) were calculated from impinger data, all that: were available for the past. Cumulative exposures as high as 2000 mpcf.y were recorded in the Quebea cohort, 10 times higher overall than exposures in Charleston. Figure 1 shows that, for the samed cumulative exposure, the risk of respiratory cancer was about 50 times higher in Charleston. These estimates of risk were essentially corroborated by independent studies in the Charleston plant $t^{6-8}$ and in Quebec.' Studies in two other textile plants, one in the United States and another in the United Kingdom $\vec{Q}$ gave similar results. ${ }^{11}$

The large difference in risk between mining and 


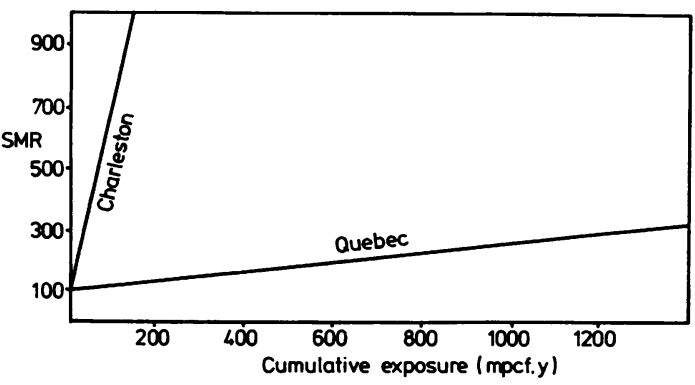

Fig 1 Exposure response for respiratory cancer in Charleston chrysotile textile and Quebec mining industries. ${ }^{35}$

textile manufacture has never been explained. Three hypotheses have been suggested: the low reliability of exposure data, the presence of longer fibres in the textile industry, and the possibility of a co-carcinogen in textile plants. There are no data to confirm or refute any of these hypotheses. Fibre type could hardly be a factor since the chrysotile used by the plant in Charleston came mostly from the Quebec mines.

Although lower dust concentrations were reported in the Charleston plant than in the mining industry, it is conceivable that textile workers who handled pure asbestos were more exposed to respirable fibres than the Quebec workers. Cumulative exposures to asbestos would then have been higher in the Charleston population and risk estimates in the two situations closer. The objective of the present study was to obtain better information on the exposure of the two cohorts. Intensity is the key question, since dates of employment and death were known precisely. Air measurements taken today are not informative, since conditions in both industries have changed enormously. It was thought that more relevant information could be obtained from examination of fibres retained in lung tissue taken at necropsy from dead cohort members.

\section{Collection of lung tissue}

The Charleston cohort comprised 2543 men, employed one month or more between 1938 and 1958. Death certificates were available for $95 \%$ of the 863 men who had died before 1 January 1978 . From these certificates, 234 necropsies were identified, 117 in one of the 11 hospitals in Charleston and the rest in 47 other hospitals, mainly in the south east of the United States. All pathology departments in Charleston were visited. The directors of the 47 other departments were contacted by letter or by telephone. To find specimens from deaths after 31 December 1977, names of cohort members were sought in recent necropsy lists. By this means we obtained a total of 77 lung specimens, including 31 paraffin blocks. In five cases the amount of lung tissue in the paraffin block was insufficient, leaving 72 cases for analysis.

The Quebec cohort comprised 10939 men born between 1891 and 1920 and employed for at least one month. By 1976, 4547 deaths had occurred. Tissue collection was limited to two hospitals, one in Thetford Mines and the other in Sherbrooke, where two thirds of the necropsied cases had died. Altogether 302 necropsies from former workers were identified, 112 before and 190 after 31 December 1975. Lung specimens were obtained for 215 , including 159 paraffin blocks.

As all the selected cases were cohort members, information was readily available on work history, cumulative exposure (mpcf.y), and cause of death. All 72 lung specimens from Charleston were analysed but, because of limited resources, only a sample of those from Quebec, comprising cases from Thetford Mines where most of the chrysotile used in the Charleston plant had come from. The selection procedure was as follows: cases from both groups were distributed in six categories of cumulative exposure (table 1). To accommodate the much higher values in the mining industry, boundaries for Thetford were set at 10 times those in Charleston. Forty three per cent of the

Table 1 Study subjects by cumulative dust exposure

\begin{tabular}{|c|c|c|c|c|c|c|}
\hline & \multicolumn{6}{|c|}{ Cumulative exposure categoris } \\
\hline & 1 & 2 & 3 & 4 & 5 & 6 \\
\hline $\begin{array}{l}\text { Charleston } \\
\text { Thetford }\end{array}$ & $\begin{array}{l}-3 \\
-30\end{array}$ & $\begin{array}{l}-9 \\
-90\end{array}$ & $\begin{array}{l}=27 \\
-270\end{array}$ & $\begin{array}{l}e s\left(m p c f . y^{*}\right) \\
-81 \\
-810\end{array}$ & $\begin{array}{l}-243 \\
-2430\end{array}$ & $\begin{array}{r}729 \\
-7290\end{array}$ \\
\hline $\begin{array}{l}\text { Charleston } \\
\text { Thetford: available } \\
\text { Thetford: selected }\end{array}$ & $\begin{array}{l}31 \\
11 \\
11\end{array}$ & $\begin{array}{l}10 \\
10 \\
10\end{array}$ & $\begin{array}{l}11 \\
37 \\
18\end{array}$ & $\begin{array}{c}\text { Cases } \\
13 \\
46 \\
23\end{array}$ & $\begin{array}{r}7 \\
41 \\
20\end{array}$ & $\begin{array}{l}0 \\
7 \\
7\end{array}$ \\
\hline $\begin{array}{l}\text { Charleston } \\
\text { Thetford }\end{array}$ & $\begin{array}{l}0.34(3.7) \\
3.9(3.0)\end{array}$ & $\begin{array}{r}5 \cdot 3(1 \cdot 3) \\
50 \cdot 5(1 \cdot 4)\end{array}$ & $\begin{array}{c}\text { metric mean } \\
17.9(1 \cdot 2) \\
177.0(1 \cdot 3)\end{array}$ & $\begin{array}{c}\text { mulative expos } \\
48.6(1.4) \\
515.0(1.4)\end{array}$ & $\begin{array}{l}(S D) \\
123(1 \cdot 3) \\
1218(1 \cdot 3)\end{array}$ & $\overline{2923}(1 \cdot 2)$ \\
\hline
\end{tabular}

*Million of particles per cubic foot.years. 
Table 2 Characteristics of cases studied

\begin{tabular}{|c|c|c|c|c|c|c|}
\hline & \multicolumn{3}{|c|}{ Charleston $(n=72)$} & \multicolumn{3}{|c|}{ Thetford $(n=89)$} \\
\hline & Median & Mean & $(S D)$ & Median & Mean & $(S D)$ \\
\hline $\begin{array}{l}\text { Age at first employment } \\
\text { Age at death } \\
\text { Years of employment } \\
\text { Years of latency } \\
\text { Years after employment } \\
\text { Intensity of exposure to dust (mpcf*) }\end{array}$ & $\begin{array}{r}22 \cdot 0 \\
58 \cdot 0 \\
6.4 \\
32 \cdot 7 \\
20 \cdot 3 \\
1.4\end{array}$ & $\begin{array}{r}24 \cdot 2 \\
55 \cdot 8 \\
13.5 \\
31.6 \\
18 \cdot 1 \\
1.9\end{array}$ & $\begin{array}{l}(6.2) \\
(9.7) \\
(14.3) \\
(8.1) \\
(13.2) \\
(1.9)\end{array}$ & $\begin{array}{r}23.0 \\
68.0 \\
36.0 \\
46.6 \\
8.0 \\
10.9\end{array}$ & $\begin{array}{l}23 \cdot 8 \\
67 \cdot 5 \\
32 \cdot 6 \\
44 \cdot 2 \\
11.6 \\
19.5\end{array}$ & $\begin{array}{l}(8 \cdot 3) \\
(9 \cdot 7) \\
(14 \cdot 7) \\
(10 \cdot 6) \\
(13 \cdot 3) \\
(21 \cdot 0)\end{array}$ \\
\hline
\end{tabular}

*Million of particles per cubic foot.

Charleston cases fell below 3 mpcf.y, the rest almost equally distributed between categories 2 to 5 . Most cases in Thetford were in categories 3,4 , and 5 , so a random sample of these was selected for analysis together with all cases in categories 1,2 , and 6 , yielding a total of 89.

Characteristics of the two study groups are set out in table 2. First employment in both was during the period 1920-55 at a mean age of 24. Age at death was much higher in the Thetford series and duration of employment over twice as long. Mean intensity of dust exposure (mpcf) was 10 times higher in Thetford.

In both industries the range of mpcf.y values for the necropsied group was similar to that of the cohorts from which they had come. In Charleston the distribution of mpcf.y values was also similar for necropsied cases and all deceased cohort members but in Thetford high values were overrepresented in necropsied cases. Table 3 shows the distributions by cause of death; diseases potentially related to asbestos were overrepresented in the Thetford group; better representativeness was achieved in Charleston.

\section{Analysis of retained fibres}

The 161 lung tissue specimens, 74 formalin fixed and 87 paraffin blocks, were analysed for fibres by transmission electron microscopy (TEM). Specimens were first prepared by digestion filtration techniques in a clean room using filtered chemicals and specially cleaned glassware.
For formalin fixed specimens, the portion to be $\frac{\Phi}{3}$ digested was cut, saturated in formalin for 10 minutes, and weighed in a small covered plastic vial. Wet weight os was converted into dry weight after measuring the lung $\omega$ density of an adjacent portion weighed wet and again $\infty$ after drying for two days in an oven at $62^{\circ} \mathrm{C}$. The wet $\mathrm{O}$ portion was digested at room temperature for 60-90 minutes with fresh commercial bleach in a disposable 3 Nalgene $100 \mathrm{ml}$ centrifuge tube. The volume of bleach was adjusted to achieve the digest concentration of 1 今 $\mathrm{mg}$ dry weight $/ \mathrm{ml}$. A standard $15 \mathrm{ml}$ aliquot was $\vec{\bullet}$ filtered through a membrane filter (Millipore stan- 0 dard, $0.45 \mu \mathrm{m}, 25 \mathrm{~mm}$ ). A spare filter was obtained in the same way. The Millipore filter was placed in a 50 o $\mathrm{ml}$ glass bottle, the side with the filtration residue applied to the glass, and ashed overnight in a low temperature asher (100 Watts forward power, $10 \mathrm{cc} \frac{\mathrm{O}}{\mathrm{D}}$ $\mathrm{O}_{2} / \mathrm{min}$ ). After ashing, bottles were completely filled $\cong$ with $50 \mathrm{ml}$ of water. One hour later, the suspension $\overline{\bar{O}}$ was filtered through Nuclepore membrane filter 3 $(0.2 \mu \mathrm{m}, 25 \mathrm{~mm}$, shiny side up) and collected particles were transferred on to TEM grids $(\mathrm{Cu}, 200 \mathrm{mesh})$ using the classic technique of the replica in a carbon film. ${ }^{12}$ Five grids were prepared from five randomly selected locations of the membrane.

Paraffin blocks were first trimmed with cleaned disposable blades to remove excess paraffin and held $\delta$ for at least three days in hot xylene $\left(64^{\circ} \mathrm{C}\right)$ to melt and dissolve the wax. This operation was conducted in a 을 specially designed dewaxing cell, containing a $75 \mathrm{ml}$ glass syringe mounted on a metallic Millipore filter

Table 3 Cause of death for cases in the study and deceased cohort members

\begin{tabular}{|c|c|c|c|c|}
\hline \multirow[b]{2}{*}{ Causes of death (ICD) } & \multicolumn{2}{|l|}{ Charleston } & \multicolumn{2}{|l|}{ Thetford } \\
\hline & Necropsied cases & Cohort members & Necropsied cases & Cohort members \\
\hline $\begin{array}{l}\text { Lung cancer }(162-4) \\
\text { Mesothelioma* } \\
\text { Gastrointestinal cancers }(150-4) \\
\text { Pneumoconiosis }(523-4) \\
\text { Other }\end{array}$ & $\begin{array}{l}7(9 \cdot 7 \%) \\
0 \\
2 \quad(2 \cdot 8 \%) \\
6 \quad(8 \cdot 3 \%) \\
57(79 \cdot 2 \%)\end{array}$ & $\begin{aligned} & 66(7 \cdot 7 \%) \\
& 1(0.01 \%) \\
& 24(2 \cdot 8 \%) \\
& 21(2 \cdot 4 \%) \\
& 745(86.9 \%)\end{aligned}$ & $\begin{array}{r}22(24 \cdot 7 \%) \\
4(4 \cdot 5 \%) \\
4(4 \cdot 5 \%) \\
11(10 \cdot 9 \%) \\
48(53 \cdot 9 \%)\end{array}$ & $\begin{aligned} 250 & (5.6 \%) \\
10 & (0.02 \%) \\
242 & (5.4 \%) \\
46 & (1.0 \%) \\
3915 & (87.8 \%)\end{aligned}$ \\
\hline All & 72 & 857 & 89 & 4463 \\
\hline
\end{tabular}

*Variously coded. ${ }^{35}$ 
holder for filtration under pressure. The lung was then removed and the xylene, while still hot, pushed by the plunger through a membrane f filter (Millipore standard, $0.8 \mu \mathrm{m}, 25 \mathrm{~mm}$ ). The dewaxed lung specimen was dried, weighed, digested, and prepared as described for the wet specimens. To correct for fibres escaping from the lung specimen during dewaxing, an adjusted portion of the xylene filter and the lung digest filter were ashed in the same bottle and the two pooled filters processed together.

TEM analyses were made with a JEOL $100 \mathrm{CX}$ electron microscope fitted with a PGT system IV energy dispersive spectrometer (EDS) for elemental analysis. Grids were inserted in a graphite sample holder tilted at $30^{\circ}$ towards the EDS detector positioned as close as possible to the grid. They were observed in the transmission mode at $\times 10000$ nominal screen magnification under $80 \mathrm{kV}$ accelerating voltage. All visible fibres (aspect ratio $>3: 1$ ) longer than $5 \mu \mathrm{m}$ were identified and sized.

Fibre types were recognised on line by an experienced microscopist from morphological features and EDS spectrum ${ }^{13}$; selected area electron diffraction was used to a limited extent. For each recognised fibre type, representative EDS spectrums were stored on disk and the fibres photographed. The same was done systematically for all fibres of unrecognised type.

Each fibre was sized (length and diameter) directly from the screen. The projected diameter of the thinnest fibres was measured to the nearest $0.03 \mu \mathrm{m}$ using a specially designed hemispherical eyepiece graticule mounted within the binocular lens of the microscope. The length of all fibres and the projected diameter of larger fibres were measured to the nearest $0.07 \mu \mathrm{m}$ using two concentric circles $(10 \mathrm{~mm}$ and $50 \mathrm{~mm}$ diameter) drawn on the fluorescent screen. As most of the fibres observed were isolated and without complicated morphology, this was usually easy. A few bundles of chrysotile were observed however; for these, the diameter of the compact core was recorded. Fibre dimensions were reported in a matrix of 120 size categories designed to allow classification in three blocks: optic fibres, Stanton fibres, and short fibres as

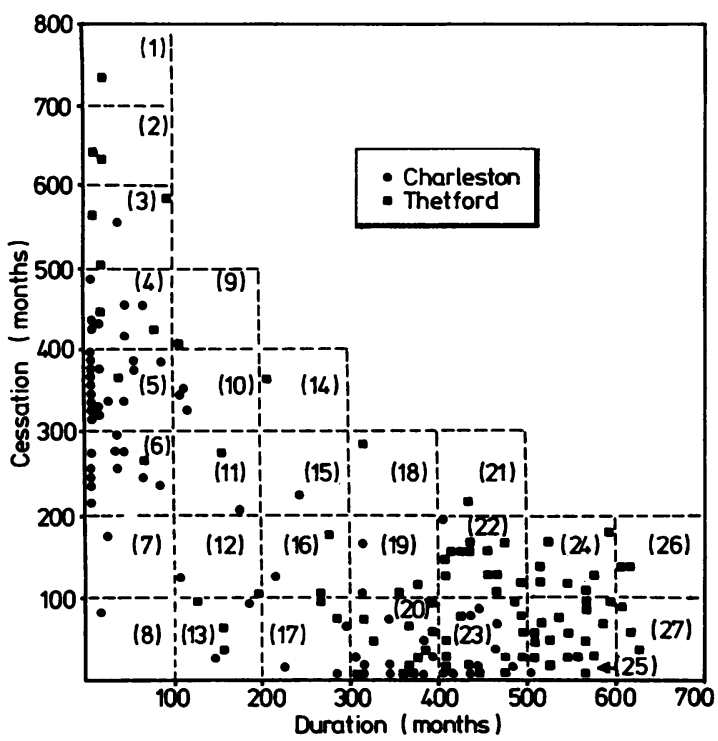

Fig 2 Distribution of subjects by months of employment (duration) and months since last employment (cessation).

\section{defined by Sebastien. ${ }^{14}$}

For each fibre type, numerical concentrations of fibres longer than $5 \mu \mathrm{m}$ per microgram of dried lung were reported. A sufficient number of grid openings was scanned to achieve a detection limit as low as $0 \cdot 1 \mathrm{f} / \mu \mathrm{g}$.

\section{Statistical analysis}

Our object was to extract information on intensity of past exposure to asbestos from lung retention measurements. We made the simple assumption that for a given fibre type, lung retention depended on duration of employment, mean intensity of exposure, and time since last employment (cessation). On this assumption, lung retention in cases with similar time characteristics, duration and cessation, should reflect mean intensity.

Table 4 Size distribution of chrysotile and tremolite fibres in lung tissue

\begin{tabular}{|c|c|c|c|c|c|c|c|c|c|}
\hline & \multirow{2}{*}{$\begin{array}{l}\text { No of } \\
\text { fibres } \\
\text { sized* }\end{array}$} & \multicolumn{5}{|c|}{ Percentage distribution length categories ( $\mu \mathrm{m}$ ) } & \multirow{2}{*}{$\begin{array}{l}\text { Mean length } \\
(\mu \mathrm{m})\end{array}$} & \multirow{2}{*}{$\begin{array}{l}\text { Mean diameter } \\
(\boldsymbol{\mu m})\end{array}$} & \multirow{2}{*}{$\begin{array}{l}\text { Stanton fibres } \\
(\%)\end{array}$} \\
\hline & & $5 \cdot 8-8.0$ & $8 \cdot 0-12 \cdot 8$ & $12 \cdot 8-20 \cdot 5$ & $20 \cdot 5-32 \cdot 4$ & $32.4-52.4$ & & & \\
\hline $\begin{array}{l}\text { Chrysotile: } \\
\text { Charleston } \\
\text { Thetford }\end{array}$ & $\begin{array}{l}226 \\
371\end{array}$ & $\begin{array}{l}72 \cdot 6 \\
67 \cdot 0\end{array}$ & $\begin{array}{l}16.4 \\
21.6\end{array}$ & $\begin{array}{l}6 \cdot 2 \\
8 \cdot 1\end{array}$ & $\begin{array}{l}3 \cdot 6 \\
2 \cdot 2\end{array}$ & $\begin{array}{l}1 \cdot 3 \\
0.8\end{array}$ & $\begin{array}{l}7.9(0.7) \\
8.3(0.6)\end{array}$ & $\begin{array}{l}0.10(0.02) \\
0.07(0.01)\end{array}$ & $\begin{array}{l}25 \cdot 2 \\
31 \cdot 8\end{array}$ \\
\hline $\begin{array}{l}\text { Tremolite: } \\
\text { Charleston } \\
\text { Thetford }\end{array}$ & $\begin{array}{l}175 \\
405\end{array}$ & $\begin{array}{l}76 \cdot 0 \\
78 \cdot 8\end{array}$ & $\begin{array}{l}17 \cdot 7 \\
17 \cdot 3\end{array}$ & $\begin{array}{l}4 \cdot 0 \\
3.7\end{array}$ & $1 \cdot 1$ & $\begin{array}{l}1 \cdot 1 \\
0 \cdot 2\end{array}$ & $\begin{array}{l}7.4(0.7) \\
6.9(0.3)\end{array}$ & $\begin{array}{l}0.35(0.04) \\
0.32(0.02)\end{array}$ & $\begin{array}{l}6 \cdot 3 \\
5 \cdot 9\end{array}$ \\
\hline
\end{tabular}

*To obtain an equal contribution from each subject the distributions were established by taking into account only the first five fibres of each type seen. 
Table 5 Concentrations of fibres in lung tissue

\begin{tabular}{|c|c|c|c|c|c|c|c|c|c|c|}
\hline \multirow[b]{2}{*}{ 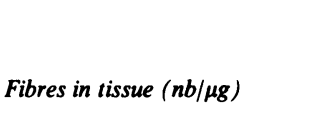 } & \multicolumn{2}{|c|}{ Chrysotile } & \multicolumn{2}{|c|}{ Tremolite } & \multicolumn{2}{|c|}{$\begin{array}{l}\text { Amosite + } \\
\text { crocidolite }\end{array}$} & \multicolumn{2}{|c|}{$\begin{array}{l}\text { Talc- } \\
\text { anthrophyllite }\end{array}$} & \multicolumn{2}{|c|}{ Other fibres } \\
\hline & $C h$ & $T m$ & $C h$ & $T m$ & $C h$ & $T m$ & $\boldsymbol{C h}$ & $T m$ & $C h$ & $T m$ \\
\hline $\begin{array}{l}-0 \cdot 1 \\
-1 \\
-10 \\
-100 \\
-1000 \\
-10000\end{array}$ & $\begin{array}{r}15 \\
35 \\
15 \\
5 \\
2\end{array}$ & $\begin{array}{r}6 \\
10 \\
39 \\
29 \\
4 \\
1\end{array}$ & $\begin{array}{r}31 \\
17 \\
7\end{array}$ & $\begin{array}{r}1 \\
4 \\
23 \\
54 \\
6 \\
1\end{array}$ & $\begin{array}{r}49 \\
14 \\
6 \\
3\end{array}$ & $\begin{array}{r}81 \\
3 \\
4 \\
1\end{array}$ & $\begin{array}{r}46 \\
23 \\
3\end{array}$ & $\begin{array}{r}51 \\
13 \\
23 \\
2\end{array}$ & $\begin{array}{l}40 \\
27 \\
22\end{array}$ & $\begin{array}{r}40 \\
25 \\
7\end{array}$ \\
\hline $\begin{array}{l}\text { Geometric mean (nb/ } \mu \mathrm{g}) \\
\text { Geometric standard deviation }\end{array}$ & $\begin{array}{l}0.63 \\
7 \cdot 3\end{array}$ & $\begin{array}{l}5 \cdot 3 \\
7 \cdot 7\end{array}$ & $\begin{array}{l}0 \cdot 38 \\
7 \cdot 5\end{array}$ & $\begin{array}{r}18 \cdot 4 \\
5 \cdot 4\end{array}$ & $\begin{array}{l}0 \cdot 14 \\
4 \cdot 9\end{array}$ & $\begin{array}{l}0.07 \\
3 \cdot 0\end{array}$ & $\begin{array}{l}0.11 \\
2 \cdot 8\end{array}$ & $\begin{array}{r}0.22 \\
5 \cdot 9\end{array}$ & $\begin{array}{l}0 \cdot 16 \\
3 \cdot 5\end{array}$ & $\begin{array}{l}0 \cdot 24 \\
4 \cdot 8\end{array}$ \\
\hline
\end{tabular}

Each fibre type was treated separately and analyses made in two ways, by stratification and in matched pairs. In both methods lung retention of fibre and mean intensity of dust exposure (mpcf) were compared between Charleston and Thetford in cases having similar duration and cessation. For the stratification analysis, cases were grouped in duration cessation cells as indicated in fig 2 . For the paired analysis, Charleston and Thetford cases were matched on both duration and cessation as closely as possible. Thirty two pairs were constituted which differed in duration and cessation by less than four years.

\section{Results}

Five main types of fibre were identified: chrysotile, tremolite, amosite, crocidolite, and talc-anthophyllite; other fibre types included rutile, micas, iron, silica, and unidentified silicates.

\section{CHR YSOTILE}

A total of 1828 chrysotile fibres, including two bundles, were analysed. Good quality EDS spectrums obtained from fibres larger than $\mathbf{0 . 2} \mu \mathrm{m}$ showed up to $50 \%$ magnesium leaching in almost all. There was some indication that the degree of the leaching was related to time between first employment and death. For chrysotile fibres of smaller diameter, EDS spectrums were not suitable for quantitative elemental analysis.

Most of fibres were around $0.06 \mu \mathrm{m}$ in diameter (table 4). Some slightly larger fibres were seen, especially in Charleston specimens. The longest fibre $(62 \mu \mathrm{m})$ was found in a Thetford specimen. The length distributions in Charleston and Thetford were similar, although the proportion of very long fibres $(>32.8 \mu \mathrm{m}$ ) based on very small numbers (three or less) was higher in Charleston. Numerical concentrations, over six orders of magnitude, were higher overall in Thetford (table 5).

Results of the stratification analysis are reported in table 6. Twenty seven duration cessation cells were defined (fig 2) but in only 14 from which results are $\vec{\sigma}$ shown were there both Charleston and Thetford cases. $\omega$ In each of the 14 cells the median of mpcf values, lung $\vec{\infty}$ concentrations of chrysotile fibres and lung concentra- 0

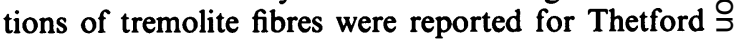
and Charleston. The chrysotile concentrations from $\overrightarrow{7}$ Thetford exceeded those from Charleston in 12 of the 14 cells; the two exceptions were those with long duration and short cessation. The geometric mean ratios (Thetford/Charleston) were $\mathbf{6 . 7 0}$ for $\mathrm{mpcf}$ and 9.69 for chrysotile concentrations (table 6).

The matched pair analysis is presented in table 7. For each pair, the ratios (Thetford/Charleston) of mpcf indices and of chrysotile concentrations were calculated; geometric means over the 32 pairs were closely similar (4.8 and $4 \cdot 3)$.

\section{TREMOLITE}

Overall, tremolite fibres were more numerous than chrysotile; a total of $\mathbf{3 2 7 0}$ was analysed, all single fibres. Their diameters were generally sufficient for quantitative elemental analysis by EDS. Fibres in the specimens from Charleston and Thetford had similar elemental composition (fig 3). Size distributions (table 4) were almost the same in the two groups, but again the proportion of very long fibres was somewhat higher in Charleston.

As for chrysotile, numerical concentrations were $\rightarrow$ higher in Thetford; they did not exceed $10 \mathrm{f} / \mu \mathrm{g}$ in Charleston, whereas the highest concentration in $N$ Thetford was over $2700 \mathrm{f} / \mu \mathrm{g}$. In the stratification analysis (table 6) median values were systematically 0 lower in Charleston, especially in cells with short $\mathrm{\omega}$ duration and long cessation. The geometric mean ratio was $23.00,3.4$ times greater than the mpcf ratio $(6 \cdot 70)$. In the matched pair analysis (table 7) the geometric $\bar{\varnothing}$ mean ratio was $12.3,2.6$ times greater than the mpcf $\stackrel{?}{?}$ ratio (4.8). As will be discussed below, however, there $T$ is reason to believe that the proportion of tremolite in dust was substantially greater in Thetford than in Charleston. 
Table 6 Median values for exposure intensity (mpcf) and lung fibre concentrations in duration cessation cells (fig 2)

\begin{tabular}{|c|c|c|c|c|c|c|c|c|c|c|}
\hline \multirow[b]{2}{*}{ Cell No* } & \multirow{2}{*}{$\begin{array}{l}\text { Cessation } \\
\text { (months) }\end{array}$} & \multirow{2}{*}{$\begin{array}{l}\text { Duration } \\
\text { (months) }\end{array}$} & \multicolumn{2}{|l|}{ No } & \multicolumn{2}{|l|}{$m p c f$} & \multicolumn{2}{|c|}{ 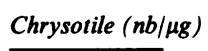 } & \multicolumn{2}{|c|}{ Tremolite $(n b / \mu g)$} \\
\hline & & & $T m$ & $C h$ & $T m$ & $C h$ & $T m$ & $C h$ & $T m$ & $C h$ \\
\hline $\begin{array}{r}3 \\
4 \\
5 \\
6 \\
6 \\
11 \\
12 \\
13 \\
16 \\
17 \\
19 \\
20 \\
22 \\
23 \\
25\end{array}$ & $\begin{array}{l}500- \\
400- \\
300- \\
200- \\
200- \\
100- \\
100- \\
100- \\
100- \\
<100 \\
<100 \\
<100 \\
<100 \\
<100\end{array}$ & $\begin{array}{l}<100 \\
<100 \\
<100 \\
<100 \\
100- \\
100- \\
200- \\
300- \\
400- \\
100- \\
200- \\
300- \\
400- \\
500-\end{array}$ & $\begin{array}{r}3 \\
2 \\
1 \\
1 \\
1 \\
1 \\
3 \\
2 \\
2 \\
2 \\
11 \\
12 \\
12 \\
17 \\
70\end{array}$ & $\begin{array}{r}1 \\
7 \\
17 \\
11 \\
1 \\
1 \\
2 \\
1 \\
3 \\
2 \\
9 \\
1 \\
9 \\
1 \\
66\end{array}$ & $\begin{array}{r}3.86 \\
50.87 \\
1.43 \\
0.70 \\
4.29 \\
0.11 \\
1.02 \\
15.25 \\
17.08 \\
67.17 \\
4.38 \\
25.62 \\
11.09 \\
12.30\end{array}$ & $\begin{array}{l}1.33 \\
2.71 \\
2.29 \\
1.05 \\
0.27 \\
2.10 \\
1.23 \\
1.29 \\
1.29 \\
1.93 \\
1.34 \\
0.50 \\
2.83 \\
1.70\end{array}$ & $\begin{array}{r}2.24 \\
2.48 \\
0.50 \\
6.32 \\
20.00 \\
0.28 \\
0.90 \\
9 \cdot 11 \\
485.01 \\
537.53 \\
6.73 \\
6.64 \\
7.95 \\
8.40\end{array}$ & $\begin{array}{r}1.56 \\
0.30 \\
0.31 \\
0.28 \\
1.49 \\
6.30 \\
0.60 \\
0.05 \\
0.80 \\
2.55 \\
0.76 \\
0.31 \\
9.55 \\
30.77\end{array}$ & $\begin{array}{r}4.49 \\
31 \cdot 12 \\
1.40 \\
11 \cdot 58 \\
1 \cdot 60 \\
0 \cdot 14 \\
1 \cdot 30 \\
41 \cdot 10 \\
10 \cdot 18 \\
45 \cdot 44 \\
16 \cdot 49 \\
39.90 \\
27 \cdot 07 \\
29 \cdot 60\end{array}$ & $\begin{array}{r}0.05 \\
0.05 \\
0.05 \\
0.10 \\
1.49 \\
\\
0.05 \\
0.90 \\
1.87 \\
0.63 \\
0.90 \\
4.05 \\
11.19 \\
4.20\end{array}$ \\
\hline \multicolumn{2}{|c|}{$\begin{array}{l}\text { Geometric mean (GM) } \\
\text { GM ratio } \mathrm{Tm} / \mathrm{Ch}\end{array}$} & & & & \multicolumn{2}{|c|}{$\begin{array}{c}7.30 \\
6.70\end{array}$} & \multicolumn{2}{|c|}{${ }_{9.69}^{8.04}$} & \multicolumn{2}{|c|}{${ }^{10.81} 23.00^{0.47}$} \\
\hline
\end{tabular}

*See fig 2 for explanation.

COMMERCIAL AMPHIBOLES AND OTHER FIBRES Non-trivial concentrations $(>0 \cdot 1 \mathrm{f} / \mu \mathrm{g})$ of amosite and crocidolite were measured in $32 \%$ of specimens from Charleston and 9\% from Thetford. In Charleston

Table 7 Lung fibre concentrations and exposure (mpcf) in 32 pairs matched for duration and cessation

\begin{tabular}{|c|c|c|c|c|}
\hline \multicolumn{2}{|c|}{ Pairs $(n=32)$} & \multicolumn{3}{|c|}{ Thetford/Charleston ratio } \\
\hline \multirow{2}{*}{$\begin{array}{l}\text { Mean } \\
\text { duration } \\
\text { (months) }\end{array}$} & \multirow{2}{*}{$\begin{array}{l}\text { Mean } \\
\text { cessation } \\
\text { (months) }\end{array}$} & \multirow{2}{*}{$\begin{array}{l}\text { Exposure } \\
\text { (mpcf) }\end{array}$} & \multicolumn{2}{|c|}{ Lung fibre concentration } \\
\hline & & & Chrysotile & Tremolite \\
\hline $\begin{array}{r}7 \\
9 \\
18 \\
46 \\
62 \\
68 \\
99 \\
110 \\
149 \\
190 \\
290 \\
292 \\
306 \\
312 \\
314 \\
351 \\
352 \\
355 \\
378 \\
389 \\
391 \\
404 \\
411 \\
420 \\
427 \\
431 \\
443 \\
449 \\
467 \\
471 \\
480 \\
500\end{array}$ & $\begin{array}{r}494 \\
435 \\
558 \\
366 \\
255 \\
435 \\
399 \\
112 \\
32 \\
98 \\
169 \\
69 \\
2 \\
90 \\
35 \\
67 \\
2 \\
12 \\
14 \\
28 \\
53 \\
14 \\
6 \\
204 \\
72 \\
1 \\
6 \\
102 \\
88 \\
30 \\
8 \\
13\end{array}$ & $\begin{array}{c}0.12 \\
13.0 \\
153.0 \\
0.41 \\
0.66 \\
21.0 \\
2.5 \\
10.0 \\
4.9 \\
2.4 \\
6.9 \\
2.7 \\
71.0 \\
0.69 \\
1.7 \\
0.30 \\
23.0 \\
0.53 \\
12.0 \\
159.0 \\
16.0 \\
58.0 \\
0.03 \\
13.0 \\
3.8 \\
21.0 \\
3.3 \\
6.8 \\
27.0 \\
1.9 \\
2.5 \\
18.0\end{array}$ & $\begin{array}{c}69.0 \\
8.2 \\
1 \cdot 2 \\
1.3 \\
63.0 \\
0.05 \\
7.0 \\
3.2 \\
84.0 \\
11.0 \\
63.0 \\
65.0 \\
0.43 \\
1.5 \\
2.0 \\
116.0 \\
26.0 \\
4.3 \\
4.8 \\
336.0 \\
1.5 \\
0.59 \\
0.04 \\
15.0 \\
0.41 \\
3.7 \\
0.06 \\
0.67 \\
89.0 \\
18.0 \\
1.4 \\
0.30\end{array}$ & $\begin{array}{c}90.0 \\
615.0 \\
4.0 \\
2.8 \\
115.0 \\
5.6 \\
54.0 \\
9.3 \\
168.0 \\
126.0 \\
70.0 \\
12.0 \\
10.0 \\
18.0 \\
1.5 \\
4.5 \\
8.7 \\
1.4 \\
107.0 \\
196.0 \\
6.2 \\
2.0 \\
0.67 \\
11.0 \\
3.1 \\
19.0 \\
0.40 \\
2.7 \\
84.0 \\
0.96 \\
7.9 \\
22.0 \\
\end{array}$ \\
\hline \multicolumn{2}{|c|}{ Geometric mean } & $4 \cdot 8$ & $4 \cdot 3$ & $12 \cdot 4$ \\
\hline
\end{tabular}

commercial amphiboles were detected only in cases hired before 1940; no crocidolite was detected in cases hired after 1940. In Thetford concentrations greater than $0 \cdot 1 \mathrm{f} / \mu \mathrm{g}$ were measured in five cases. All were hired in the period 1928-36 and had been employed for many years (mean duration 39.9 years). Concentrations of talc-anthophyllite and of other fibres were both slightly higher in Thetford (table 5).

\section{Discussion}

In the absence of an accepted model for lung retention of asbestos fibres comparison between the two groups was restricted to cases having similar time characteristics of exposure (duration and cessation). In these circumstances it was assumed that retention would be proportional to mean intensity of exposure. This assumption, impossible to test without good environmental data, may be questioned, especially for chrysotile.

Initially we thought it might be appropriate to use regression analysis to relate exposure intensity (mpcf) to lung fibre concentrations in the two series and to compare observed values in one with those expected by application of the regression equations from the other. Although the results obtained by this approach were similar to those from the matched pair and stratification analyses, we have not quoted them here because the underlying assumptions as to linearity did not seem justified. As discussed below, however, we used the regression equations to estimate the relative proportions of tremolite in the two plants.

The representativeness of the two groups of necropsies is also uncertain. The cases studied adequately covered the range of cumulative exposure (mpcf.y) in the two cohorts but asbestos related diseases were 


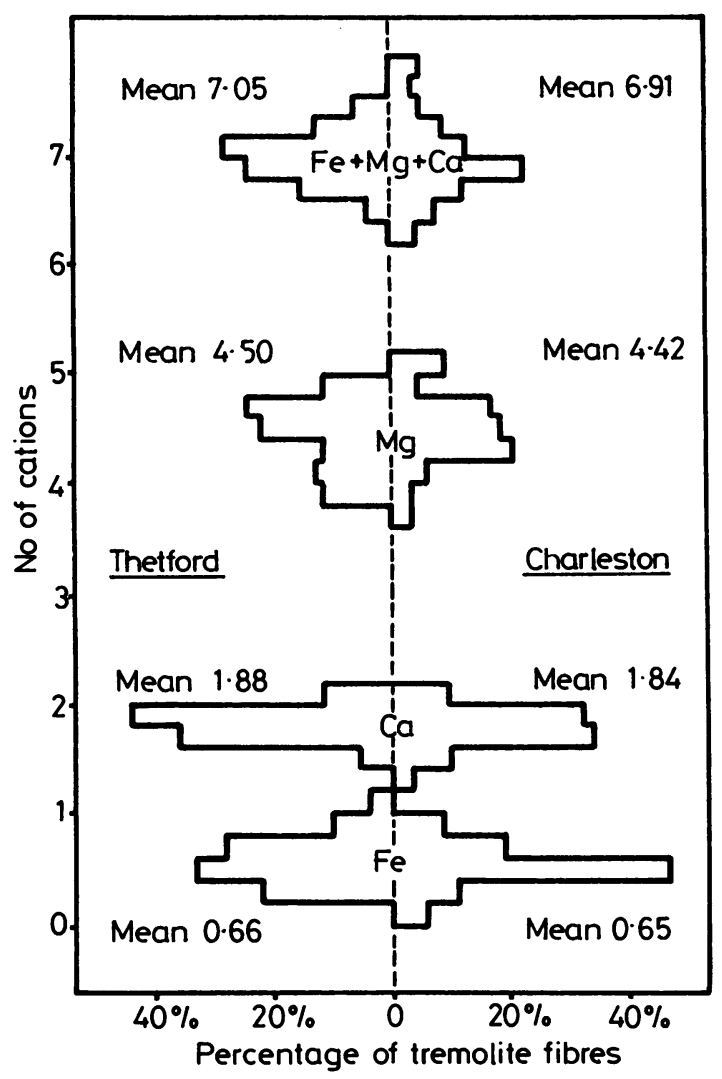

Fig 3 Distributions of elemental compositions of tremolite fibres in lung tissue, determined by energy dispersive spectrometry using peak ratio method. ${ }^{13}$ Numbers of $\mathrm{Fe}, \mathrm{Ca}$, $\mathrm{Mg}$ cations were calculated as for 8 silicon atoms to allow comparison with ideal formula for tremolite: $\mathrm{Ca}_{2}(\mathrm{Mg}, \mathrm{Fe})$, $\left(\mathrm{Si}_{8} \mathrm{O}_{26}\right)(\mathrm{OH})_{2}$.

overrepresented in the Thetford series. As exclusion of such cases from the matched pair analysis yielded similar results, this bias was probably not important.

The presence of longer fibres in the textile industry has often been proposed as the explanation of the higher risk in Charleston. Our study does not support this hypothesis; as the lung preferentially retains long fibres and our size selective analysis was orientated towards fibres longer than $5 \mu \mathrm{m}$, any difference in size distributions should have been picked up.

The lung tissue analyses confirmed exposure to chrysotile but gave even stronger evidence of exposure to tremolite in both industrial groups. In all duration cessation cells, except that for short exposures in Charleston, the concentration of tremolite was higher than that of chrysotile. In the Thetford group tremolite represented $77 \%$ of all asbestos fibres analysed. As the proportion of tremolite in asbestos
Sébastien, McDonald, McDonald, Case, Harley dust from the Thetford region has been estimated at $\frac{\mathbb{D}}{2}$
around $1 \%,{ }^{15}$ the respiratory system clearly treats tremolite differently from chrysotile. The explanations] probably lies mainly in the more rapid clearance ofo chrysotile, ${ }^{16}$ the mechanism of which is unknown. Tremolite with the same elemental composition wasc found in lung tissue from Thetford and Charleston $\stackrel{\varnothing}{\Omega}$ cases, implying a common source and suggesting that tremolite may accompany chrysotile from production ${ }^{\infty}$ into its industrial applications.

Although these findings put in question the relative $\vec{\overrightarrow{ }}$ importance of tremolite and chrysotile in asbestos $\omega$ related pathology, they give no indication that tremolite was responsible for the higher risk of lung 3 cancer in Charleston. In fact, both stratification and $\vec{\rho}$ matched pair analyses indicate the reverse. In cells of $\omega$ short duration and long cessation (table 6) the $-\dot{\infty}$ tremolite retention was much higher in Thetford; eveno at longer durations a substantial difference remained.음

In the matched pair analysis (table 7) the meantremolite ratio (Thetford/Charleston) was 12.43 whereas the mean mpcf ratio was only $4 \cdot 8$. We have no direct evidence, however, on the proportion of ${ }^{-}$ tremolite in dust at the two places. Linear regressionco analyses showed that the proportion of tremolite inco pulmonary fibres was related to duration of employment and time since last employment. Equations relating proportion of tremolite $(\% \mathrm{~T})$ to duration of employment in months (MD) and months since lasto employment (MC) were respectively:

Charleston:

$(\% \mathrm{~T})=0 \cdot 137+9 \cdot 610^{-4}(\mathrm{MD})+5 \cdot 210^{-4}(\mathrm{MC})$ Thetford:

$(\% \mathrm{~T})=0.346+6 \cdot 710^{-4}(\mathrm{MD})+6 \cdot 310^{-4}(\mathrm{MC})$

At zero values of $\mathrm{MD}$ and $\mathrm{MC}$, these equationso should reflect the proportion of tremolite among fibres deposited in the lung before modifications byo solubility or clearance mechanisms. This suggests that the proportion of tremolite in dust was 2.5 times higher (346/137) in Thetford than in Charleston Applying this correction to the mpcf indices in theo matched pair analysis yielded a mean ratio of exposure intensities of 12.0 , a figure close to the 12.4 ratio foro tremolite. Similar correction of the mpcf index in the stratification analysis brought the value from 6.7 toos 16.8 also fairly close to 23.0 , the ratio for tremolite. N

In the matched pair analysis, the mean mpcf ration and the mean chrysotile ratios were similar. This implies that the midget impinger measurements adequately reflected exposure to chrysotile in both? industries. Overall, the findings imply that exposures? to asbestos were substantially higher in Thetford than in Charleston and even suggest that the impingero measurements adequately reflected exposure to both chrysotile and tremolite, provided that a $2 \cdot 5$ correction factor is applied to the latter. This conclusion is in? 
agreement with the fact that conversion factors (f/cc/ mpcf) worked out by Dement $e t$ al ${ }^{6}$ and by Gibbs and Lachance, ${ }^{17}$ were similar in the two industries. The hypothesis of a systematic underestimation of exposures to asbestos in Charleston, which would have accounted for the difference in risk, must therefore be rejected and other explanations sought.

The possible presence of co-carcinogens at the textile plant deserves consideration. During a 20 to 30 year period (1925-54), mineral oil was sprayed on to the asbestos stock to reduce dust concentrations and facilitate the process. Apparently, this was a common practice in the asbestos textile industry. ${ }^{18}$ Mineral oil may itself be carcinogenic ${ }^{19}$ and, in addition, it could conceivably enhance the action of cigarette smoke. At present, we see no way of testing this hypothesis.

Requests for reprints to: Dr P Sebastien, Groupe Pneumopathies Professionnelles, GERCHAR, BP2, 60550 Verneuil en Halatte, France.

\section{References}

1 Ayer HE, Lynch JR, Fanney JH. A comparison of impinger and membrane filter techniques for evaluating air samples in asbestos plants. Ann NY Acad Sci 1965;132:274-87.

2 McDonald JC, McDonald AD. Epidemiology of asbestos-related lung cancer. In: Antmann K, Hisner J, eds. Asbestos-related malignancy. Orlando, Florida: Grove \& Stratton Inc, 1986; 57-79.

3 McDonald JC, Liddell FDK, Gibbs GW, Eyssen GE, McDonald AD. Dust exposure and mortality in chrysotile mining 1910-75. Br J Ind Med 1980;37:11-24.

4 Liddell FDK, Thomas DC, Gibbs GW, McDonald JC. Fibre exposure and mortality from pneumoconiosis, respiratory and abdominal malignancies in chrysotile production in Québec., 1926-75. Ann Acad Med Singapore 1984;13(suppl):340-4.

5 McDonald AD, Fry JS, Woolley AJ, McDonald JC. Dust exposure and mortality in an American chrysotile textile plant. Br J Ind Med 1983;40:361-7.

6 Dement JM, Harris Jr RL, Symons MJ, Shy CM. Estimates of dose-response for respiratory cancer among chrysotile asbestos textile workers. Ann Occup Hyg 1982;26:869-87.

7 Dement JM, Harris Jr RL, Symons MJ, Shy CM. Exposures and mortality among chrysotile asbestos workers. Part I: Exposure estimates. Am J Ind Med 1983;4:399-419.

8 Dement JM, Harris Jr RL, Symons MJ, Shy CM. Exposures and mortality among chrysotile asbestos workers. Part II: Mortality. Am J Ind Med 1983;4:421-33.

9 Nicholson WJ, Selikoff IJ, Seidman H, et al. Long term mortality experience in chrysotile miners and millers in Thetford Mines, Québec. Ann NY Acad Sci 1979;330:11-21.

10 McDonald AD, Fry JS, Woolley AJ, McDonald JC. Dust exposure and mortality in an American factory using chrysotile, amosite, and crocidolite in mainly textile manufacture. $\mathrm{Br} J$ Ind Med 1983;40:368-74.

11 Peto J, Doll R, Hermon C, Binns N, Clayton R, Goffe T. Relationship of mortality to measures of environmental asbestos pollution in an asbestos textile factory. Ann Occup Hyg 1985;29:305-55.

12 Chatfield EJ. Short mineral fibres in airborne dust. In: Proceedings of a symposium on short and thin mineral fibres. Identification, exposure and health effects. Solna: National Board of Occupational Safety and Health Research Department, 1983:9-81.

13 Sébastien P, Gaudichet A, Billon-Galland MA, Janson X. Spectrometrie X par dispersion d'énergie en microscopie électronique à transmission: application à la caractérisation des fibres minérales. Journal de Microscopie et de Spectroscopic Electronique 1980;5:83-97.

14 Sébastien P. Measuring asbestos dust in the environment. In: Proceeding of a symposium on asbestos, its health risks, analysis, regulation and control. Pittsburgh: APCA 1987:97-108.

15 Sébastien P, Plourde M, Robb R, Ross M. Ambiant air asbestos survey in Québec mining towns. Part 2. Main study. Environment Canada. Ottawa 1986. (Report No: EPS/AP/RQ-2E.) 1986.

16 Sébastien P, Begin R, Case BW, McDonaldd JC. Inhalation of chrysotile dust. In: Wagner JC, ed. Accomplishments in oncology. Philadelphia: JB Lippincott, 1986:19-29.

17 Gibbs GW, Lachance M. Dust exposure in the chrysotile asbestos mines and mills of Québec. Arch Environ Health 1972;24: 189-97.

18 Laires A, Borba H, Rueff J, Golmes MI, Halpern M. Urinary mutagenicity in occupational exposure to mineral oils and iron oxide particles. Carcinogenesis 1982;3:1077-9.

19 International Agency for Research on Cancer. Monographs on the evaluation of the carcinogenic risk of chemicals to humans. Polynuclear aromatic compounds. Part 2. Carbon blacks, mineral oils and some nitroarenes. Lyon: IARC, 1984. 